\title{
QUALIFICATION OF CONCEPTS AND ITS PROBLEMS IN CASES WITH FOREIGN ELEMENT IN POLAND AND THE UNITED KINGDOM
}

\begin{abstract}
Qualification is the basic instrument used in the process of application of the law. It is impossible to apply the law without conducting it. The main internal source of collision law in Poland, Act of private international law dated February $4^{\text {th }}, 2011$, does not specify how to carry on the process of the qualification, and doctrine is of the opinion that the Polish court applying foreign law should interpret the foreign concepts according to the rules of this law and give them such meanings as this law assigns to them. But also there are four doctrinal proposals concerning methods of qualification. The first one (with various modifications) is relatively popular in a number of countries, while the Polish doctrine has the greatest respect for the latter: 1) lex fori approach, 2) lex causae approach, 3) autonomous method and 4) functional method (or collision lex fori approach).

The English judge applying the rules derived from his own internal law remembers about the function of private international law - and therefore takes into account the rules and institutions adopted in the foreign laws. That is application of lex fori approach modified because of the function of collision law, indeed reminiscent of a functional method. However, due to the lack of a uniform approach to qualification and identification of the only way to proceed by the doctrine and case law, it is permissible to move away from the use of this method. For instance it is possible to use the lex causae approach, if it leads to an equitable solution.

Lack of regulation of qualification gives a person applying the law a freedom, but at the same time leads to uncertainty about the effects.
\end{abstract}

The main internal source of collision law in Poland is Act of private international law dated February $4^{\text {th }}, 2011$. It settles the law applicable to the private law relations connected with more than one country, containing general regulations of application of collision norms and specific collision norms responsible for choice of law in specific cases. However, it does not specify how to carry on the process of the qualification of concepts (notions), and doctrine is of the opinion that the Polish court applying foreign law should interpret the foreign concepts according to the rules of this law and 


\section{Katarzyna Bagan-Kurluta}

give them such meanings as this law assigns to them. The Act also does not indicate what should be interpreted in the process of qualification and does not define qualification.

According to M. Pazdan (2009, pp. 55-56) the qualification is the interpretation of the expressions describing the scope of the collision norm undertaken in order to establish the conditions for its use. This narrow understanding of qualification as process concerning only the scope of the collision norm was extended in the doctrine. Qualification process shall also be applied in relation to the concepts being a part of the point of contact in the collision norm. As a result, qualification in a broader sense can be defined as the interpretation of expressions/notions used in the collision norm in order to apply this norm - and therefore also as subsumption, an assignment of the facts in the process of application of law formulated by the interpretation of the notions used in the rules of collision law. If, however, the qualification of the scope of collision norm consists of both interpretation and subsumption, it is enough to provide interpretation only while qualifying the point of contact.

The method of qualification process may vary depending on the time when it is used. Owing to the French scholar, E. Bartin (1930, p. 565 and next), the division of qualification exists in the Polish doctrine - there is a primary and secondary qualification. From the point of view of this division, the most important is the fact (moment) of an indication of the applicable/proper law, as the first one takes place before the indication and the second - just after it. Therefore, we assume that the primary qualification applies to the forum law rules (collision norms), and secondary - to norms (as it seems, not only of conflict law) of the indicated law and their correct application.

In the absence of a statutory reference how to carry on the qualification process, the proposals come from the doctrine. It provides four different approaches - methods of qualification. The first one (with various modifications) is relatively popular in a number of countries, while the Polish doctrine has the greatest respect for the latter: 1) lex fori approach, 2) lex causae approach, 3) autonomous method and 4) functional method (or collision lex fori approach). (Bagan-Kurluta, 2002, pp. 61-69; Bagan-Kurluta, 2011, pp. 126-133; Bagan-Kurluta, 2012, pp. 51-56).

Lex fori approach allows to apply the law of the forum to the interpretation of legal concepts, which means that the ways of interpretation should be found in this legal system and the meanings of the notions should be the same as in this internal (private) law. In fact it means that we should interpret the concepts provided in the rules of private international 
law the way it is done in civil law. Lex causae approach provides application of a law that would probably be proper in specific case, but it has not been chosen yet. It is perfect for secondary qualification, because it takes place after indication of law. If we know the proper law (the chosen one), we can easily apply all the rules of interpretation and also take all the meanings of legal concepts from this law. Autonomous method makes universal law out of collision law, which means that hypothetically we have one catalogue of notions being used in private international law and their universal meanings for all the countries in the world. That is untrue. The last approach underlines the importance of the international function of collision law. In a consequence of application of this method we should take the ways of interpretation and the meanings of legal concepts from our national (forum) collision law, remembering that they are different than the ones takes from our (forum) internal (civil/private) law. The problem is that in fact the methods of interpretation are the same for both - collision and private laws. The meanings can differ, because we should respect the international function of collision law, that is why we should accept the idea that the meaning of a notion in international case may be a little bit different than in the national case. For instance in a case of marriage (national one), a notion of marriage is taken from definition written in art. 18 of the Polish Constitution (Dz. U. z 1997 Nr 78, poz. 483). Marriage is an union between a man and a woman. When we have the same case, but with so called foreign element (international one) it is possible to accept the idea that the legal concept of marriage also contains the same-sex unions.

Lack of rule responsible for qualification in the Polish law can be interpreted in two ways. Firstly, it gives the possibility to apply a method chosen for a given case. Secondly, an issue of classification seems to be the more controversial as the more situations unknown to Polish law arise in courts or just as subjects of public discussion. Its best example was the discussion about a change of private international law regarding marriage, and especially a notion of marriage itself. The main question was if a draft was contrary to shown above constitutional rule regarding marriage. In fact the discourse involved not an issue of inconsistency but a method of classification of the concept of marriage.

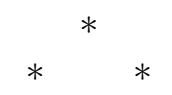

In the United Kingdom the interpretation of terms is largely based on English rules of private international law, assuming the existence of differences in meanings between collision and domestic/internal law, and assum- 


\section{Katarzyna Bagan-Kurluta}

ing that the meaning of the terms in the light of the former are wider than in the light of the latter. Definitions should be relative and functional, and besides, they should be created separately for each case, because meaning of the concept accepted in one case must not necessarily correspond to the situation in the other case. When analyzed, institution or rule of foreign law has no equivalent in the English law, the court gives it the meaning of the institution or rule closest to it, existing in the English law, it is possible to also use the analogy to the institution from the foreign law. (De Nicols v. Curlier [1900] AC 21).

The judge applying the rules derived from his own internal law remembers about the function of private international law - and therefore takes into account the rules and institutions adopted in the foreign laws (Cheshire and North's, 2004, p. 38). That is, as it seems, application of lex fori approach modified because of the function of collision law, indeed reminiscent of a functional method. However, due to the lack of a uniform approach to qualification and identification of the only way to proceed by the doctrine and case law, it is permissible to move away from the use of this method, which can take place, as it seems, accidentally.

It is therefore possible to use the lex causae approach, if it leads to an equitable solution. (In the Estate of Maldonado [1953] 3 WLR 204; [1953] 2 All ER 300; [1954] P. 223). In addition, the meaning of the notion of citizenship, as the universally used concept of international function, is determined on the basis of this law, which is used to determine its existence, and therefore the national law (Oppenheimer $v$. Cattermole [1972] 3 WLR 815), while the nature of other points of contact is determined by the English collision law. (Graveson, 1974, p. 58).

According to the principle of application of its own procedure by the court, the English court may make a performance of the contract in the light of the relevant foreign law valid and effective dependent on the compliance with the rules of the English procedure (Leroux $v$. Brown [1852] 12 CB 801) or analyze foreign concept of limitation of claims and if it corresponds with the English one, use the English procedural provisions regardless of whether the institution is a part of the procedure or substantive law in the foreign legal system. (De Reneville $v$. de Reneville [1948] P. 100). Although with regard to this last point, the court since the entry into force of the Foreign Limitation Periods Act of $1984^{1}$ should always apply the proper foreign law. However, the court may very well decide about the qualification of institutions based not on a strict division of the institutions of substantive and procedural law, but on the circumstances of the case (Re Fuld's Estate (No. 3) [1968] P. 675), or just very liberally assume that an institu- 
tion is part of the substantive law, but in fact, it is regulated by the rules of the English civil procedure (Fentiman, 1998, p. 39). Equally liberal approach to the qualification of institutions, where there is a discrepancy in the location of the institution as part of the process or the material law, is an outcome of the assertions of the doctrine, as well as of the case law in some part, with regard to the legal presumptions and burden of proof. In the case of the latter, it is suggested to choose between two methods of qualifications - the lex fori or rather the lex fori in the broader sense (Graveson, 1974, pp. 46-53; See Re Korvine's Trusts [1921] 1 Ch. 343) or the lex causae (Fentiman, 1998, pp. 40; Re Fuld's Estate (No. 3) [1968] P. 675).

Some scholars, such as A. Briggs (2007, p. 1528) consider the fact that the qualification of a situation as falling within the specific category of legal institution - that is, as part of the substantive law, the law of marriage, etc. should be held in the conceptual structures of English law, but bearing in mind that the flexible use of analogy may lead to a rational solution.

It should be assumed that the British courts generally apply a specific lex fori method described above, but they can use it in modified by a Canadian scholar, J.D. Falconbridge, form. He assumed that the qualification is a two-step process. The first stage involves the use of lex fori to define the scope of legal category (concept), the second - the analysis of the relevant foreign norm in its own context in order to determine whether it fits within the scope pre-determined by the lex fori. (Collier, 2004, pp. 17-19). This means that the courts actually do not use foreign qualification. This two-steps process is also seen by other representatives of the English doctrine. They use the division into classification of the cause of action, which enables the identification of the category of the legal institution, and the classification of a rule of law which enables the identification of the collision norm, which is to be applied, and as a consequence of its application - an indication of the applicable/proper law. (Hayward, 2006, p. 7-8, Cheshire, North's, 2004, p. 36 and next). The first one is defined by G.C. Cheshire, P. North and J.J. Fawcett as assigning the question at issue in the facts considered by the court to the relevant legal category (and thus the discovery of the true cause of claim), in order to reveal the collision norm - relevant and proper to apply. (Cheshire, North's, 2004, pp. 36; Tezcan $v$. Tezcan [1992] 87 DLR (4th) 503; Re Musuru's Estate [1936] 2 All ER 1666). The second is to apply the appropriate collision norm. While to the first of these relate all of the foregoing, the indication of the basis (i.e. on the occasion - of the method) of qualification, in the second of them it is problematic. 


\section{Katarzyna Bagan-Kurluta}

In matters related only to the area of England the base (and subject) of qualification are generally the rules provided in the domestic/national law. In cases with the foreign element, because of the specific nature of conflict of laws, even before the start of qualification of the English norm one should make sure of the purpose to be realized as a result of its application. The same can be said about qualification of foreign norms, provided that it is conducted according to the rules provided by the indicated foreign law - but again, with the objectives to be achieved as a result of their use in mind. In matters of family law doubts about the method of qualification raised in regard to issue of consent to marry, and potential conflict of qualification (here, in particular in English-French cases) while deciding about it as a material or formal prerequisite of the marriage. (Simonin $v$. Mallac [1860] 2 Sw \& Tr 67, Ogden v. Ogden [1908] P 46; Lodge v. Lodge [1963] 107 Sol Jo 437; Mahadervan $v$. Mahadervan [1964] P. 233; Shahnaz v. Rizwan [1965] 1 QB 391; Apt $v$. Apt [1947] P. 127; [1948] P. 83 (CA); [1947] 1 All ER 624; Starkowski v. Attorney-General [1954] AC 155; Graveson, 1974, pp. 53-56).

To recapitulate, the qualification is the basic instrument used in the process of application of the law. It means that it is impossible to apply the law without conducting it. Lack of regulation of qualification gives a person applying the law a sort of freedom, but at the same time leads to a kind of uncertainty about the effects. For example, this problem emerges in the case of ambiguous term, such as domicile. As a result, the method of qualification will decide whether we are dealing with domicile in a particular country. Each method has disadvantages - the use of the first, apart from the need to carry out the re-interpretation of the term, is associated with doubts as to the possibility of using all of the provisions contained in the law forum (e.g. art. 26-28 of the kodeks cywilny (Dz. U. z 1964 Nr 16, poz. 93 z późn. zm.)). The use of the second means, in turn, acceptance of a false assertion that the State determines the domicile of a person (after all, it is a relationship created by a person, not by the state). It can be assumed that this is a way of multiplication of problems connected with domicile - by denying the existence of domicile or creating a situation in which one person has more than one domicile. Analysis of utility of the third method, in turn, leads to the conclusion that it can only be used for interpretation of the Polish collision norms, so to the interpretation of foreign rules we need to apply one of the methods already mentioned here (Bagan-Kurluta, 2001, p. 106), for example, to understand it as it is understood by foreign collision law (Pazdan, 2009, p. 53). 


\section{N O T E S}

1 Art. 1 Application of foreign limitation law. (1) Subject to the following provisions of this Act, where in any action or proceedings in a court in England and Wales the law of any other country falls (in accordance with rules of private international law applicable by any such court) to be taken into account in the determination of any matter- (a) the law of that other country relating to limitation shall apply in respect of that matter for the purposes of the action or proceedings subject to section $1 \mathrm{~A}$; and (b) except where that matter falls within subsection (2) below, the law of England and Wales relating to limitation shall not so apply. (2) A matter falls within this subsection if it is a matter in the determination of which both the law of England and Wales and the law of some other country fall to be taken into account. (3) The law of England and Wales shall determine for the purposes of any law applicable by virtue of subsection (1)(a) above whether, and the time at which, proceedings have been commenced in respect of any matter; and accordingly, section 35 of the M1Limitation Act 1980 (new claims in pending proceedings) shall apply in relation to time limits applicable by virtue of subsection (1)(a) above as it applies in relation to time limits under that Act. (4) A court in England and Wales, in exercising in pursuance of subsection (1)(a) above any discretion conferred by the law of any other country, shall so far as practicable exercise that discretion in the manner in which it is exercised in comparable cases by the courts of that other country. (5) In this section "law", in relation to any country, shall not include rules of private international law applicable by the courts of that country or, in the case of England and Wales, this Act. http://www.legislation.gov.uk/ukpga/1984/16/section/1 (accessed October 25, 2012).

\section{R E F E R E N C E S}

Apt v. Apt [1947] P. 127; [1948] P. 83 (CA); [1947] 1 All ER 624.

Bagan-Kurluta K. (2012). Sprawy rodzinne w polsko-brytyjskim obrocie prawnym. Białystok: Trans Humana, 51-56.

Bagan-Kurluta, K. (2002). Kolizja kwalifikacji. Przedawnienie roszczeń. Stan aktualny - uwagi de lege ferenda, Studia Prawnicze, 152 (Volume 2), 61-69.

Bagan-Kurluta, K. (2011). Prawo prywatne międzynarodowe. Warszawa: C.H. Beck, 126-133.

Bartin E. A. (1930). La Doctrine des Qualifications et ses rapports alec la caractère national des régles du Conflit des Lois. Rec. De Cours, 1, 565 and next pages.

Briggs, A. (2007). Private International Law. In A. Burrows (ed.), English Private Law (p. 1528). Oxford: Oxford University Press, 2007).

Cheshire, North's (2004). Private International Law. LexisNexis: London, 38.

Collier, J. G. (2004). Conflict of Laws. Cambridge: Cambridge University Press, $17-19$.

De Nicols $v$. Curlier [1900] AC 21.

De Reneville $v$. de Reneville [1948] P. 100.

Fentiman, R. (1998). Foreign Law in English Courts. Pleading, Proof and Choice of Law. Oxford: Oxford University Press, 39. 
Foreign Limitation Periods Act of 1984, http://www.legislation.gov.uk/ukpga/1984 /16/section/1 (accessed October 25, 2012).

Graveson, R. H. (1974). Conflict of Laws. Private International Law. London: Sweet \& Maxwell, 58.

Hayward, R. (2006). Conflict of Laws. Sydney, London: Cavendish Publishing Limited, 7-8.

In the Estate of Maldonado [1953] 3 WLR 204; [1953] 2 All ER 300; [1954] P. 223.

Leroux $v$. Brown (1852) 12 CB 801.

Lodge $v$. Lodge (1963) 107 Sol Jo 437.

Mahadervan $v$. Mahadervan [1964] P. 233.

Ogden v. Ogden [1908] P 46.

Oppenheimer $v$. Cattermole [1972] 3 WLR 815.

Pazdan, M. (2009). Prawo prywatne międzynarodowe. Warszawa: Lexis Nexis, 5556.

Re Fuld's Estate (No. 3) [1968] P 675.

Re Korvine's Trusts [1921] 1 Ch. 343.

Re Musuru's Estate [1936] 2 All ER 1666.

Shahnaz $v$. Rizwan [1965] 1 QB 391.

Simonin v. Mallac (1860) $2 \mathrm{Sw} \& \operatorname{Tr} 67$.

Starkowski $v$. Attorney-General [1954] AC 155.

Tezcan $v$. Tezcan (1992) 87 DLR (4th) 503.

Ustawa z dnia 23 kwietnia 1964 r. Kodeks cywilny (Dz. U. z 1964 Nr 16, poz. 93). 